\title{
PERBEDAAN EFEK RESTORATIF BERDASARKAN PAPARAN VISUAL JENIS LINGKUNGAN DALAM MENINGKATKAN KESEJAHTERAAN PSIKOLOGIS INDIVIDU
}

\author{
Melok Roro Kinanthi dan Fitri Arlinkasari \\ Fakultas Psikologi Universitas YARSI \\ E-mail:melok.roro@yarsi.ac.id
}

\begin{abstract}
ABSTRAK, Penelitian ini dilakukan untuk menemukan setting lingkungan yang berpotensi meningkatkan kesejahteraan psikologis individu setelah mengalami kondisi yang penuh tekanan melalui pengukuran efek restoratif yang dirasakan oleh responden. Dengan pendekatan eksperimental, penelitian ini bertujuan melihat perbandingan efek restoratif berdasarkan perbedaan paparan visual jenis lingkungan, yaitu lingkungan natural (natural environment) dan lingkungan terbangun (built environment). Lingkungan natural (natural environment) adalah lingkungan yang terbentuk secara alamiah tanpa campur tangan manusia sedangkan lingkungan terbangun (built environment) adalah segala sesuatu yang dibuat, disusun dan dipelihara oleh manusia untuk memenuhi keperluan manusia yang menengahi lingkungan secara keseluruhan dengan hasil yang memengaruhi konteks lingkungan. Berdasarkan hasil penelitian, diketahui bahwa terdapat perbedaan atensi dan emosi yang signifikan berdasarkan jenis stimulus yang diterima responden. Artinya, jenis stimulus lingkungan yang berbeda dapat menghasilkan respon stres yang berbeda pada individu. Dengan kata lain, stimulus lingkungan yang berbeda juga berpotensi memberikan efek restoratif yang berbeda pada individu. Secara khusus, perbedaan tersebut terlihat signifikan pada aspek emosi dan atensi, namun tidak menunjukkan perbedaan signifikan pada aspek fisiologis yang diukur melalui tekanan darah. Pada aspek emosi, subjek yang mendapatkan stimulus nature menunjukkan respon emosi yang lebih positif dibandingkan subjek dengan stimulus built. Sebaliknya, pada aspek atensi, subjek yang menerima stimulus built menunjukkan peningkatan kapasitas atensi yang lebih baik dibandingkan subjek pada kelompok nature.
\end{abstract}

Kata kunci: efek restoratif; paparan visual; lingkungan natural; lingkungan terbangun

\section{THE DIFFERENCES OF RESTORATIVE EFFECTS BASED ON THE ENVIRONMENTAL VISUAL TYPES IN IMPROVING INDIVIDUALS PSYCHOLOGICAL WELL-BEING}

\begin{abstract}
This research was conducted to find potential environmental settings to improve the psychological well-being of individuals after experiencing stressful conditions through the measurement of the restorative effects felt by respondents. With an experimental approach, this study aims to look at a comparison of restorative effects based on differences in visual exposure towards environmental types i.e., natural environment and built environment. Natural environment is an environment that is formed naturally without human intervention whereas the built environment is everything that is created, compiled and maintained by humans to meet human needs in order to mediate the environment as a unit that affects the environmental context. Based on the results of the study, it is found that there are significant differences in attentions and emotions based on the type of stimulus received by respondents. Thus, different types of environmental stimuli can produce different stress responses in individuals. In other words, different environmental stimuli also have the potential to give different restorative effects to individuals. Therefore, restorative interventions to individuals can be adjusted to the type of environmental stimulus that is often experienced by individuals. Particularly, these differences appear to be significant in the emotional and attention aspects, but do not show significant differences in the physiological aspects measured by blood pressure. In the emotional aspect, subjects who get a nature stimulus show a more positive emotional response than a subject with a built stimulus. On the other hand, in the attention aspect, the subjects who received a built stimulus showed an increase in the attention capacity that was better than the subjects in the nature group.
\end{abstract}

Keywords: restorative effects; visual exposure; natural environment; built environment

\section{PENDAHULUAN}

Kota bisa menjadi sangat penuh tekanan karena bising, kemacetan, kepadatan, polusi, dan suhu udara yang berpotensi memicu agresivitas dan kekerasan (Baron \& Ransberger, 1978). Meski demikian, kota juga penuh daya tarik. Banyak individu yang tertarik dengan kota karena menawarkan beragam keuntungan seperti keberagaman kultur, kehidupan jalanan yang ramai, dan kemudahan akses terhadap fasilitas pendidikan, kesehatan, dan pekerjaan.

Tekanan di kota besar seperti Jakarta bisa semakin dirasakan oleh warganya karena kota besar juga kerap kali masalah kualitas lingkungan hidup. Menurut laporan Indeks Kualitas Lingkungan Hidup (IKLH) tahun 2014 yang dikeluarkan oleh Kementrian Lingkungan
Hidup Indonesia, kerusakan lingkungan yang dialami Jakarta bahkan sudah dalam taraf waspada, dikarenakan penyusutan ruang terbuka hijau sehingga tak lagi menawarkan fungsi paru-paru kota (Dhewanthi, 2015).

Menurut Wiwanitkit (2010), kerusakan lingkungan dapat berdampak besar terhadap psikologis individu seperti kecemasan, depresi, dan psikosis. Kerusakan lingkungan itu sendiri juga menyebabkan suatu wilayah menjadi tidak layak huni. Perubahan lingkungan inilah yang kemudian dapat memengaruhi kesejahteraan psikologis penduduknya. Sebagai contoh, semakin tinggi polusi air di suatu daerah, semakin rendah pula kebahagiaan penduduknya. Hal ini dikarenakan kualitas tempat tinggal menyebabkan penurunan kepuasan hidup dan kebahagiaan penduduknya 
secara umum. Burls (2007) menambahkan, sebanyak $80 \%$ penduduk di Inggris tinggal di kawasan urban dan menemukan sejumlah bukti kuat yang menyimpulkan bahwa berkurangnya area hijau turut mengurangi kualitas hidup penduduk kota, atau setidaknya menurunkan kesempatan individu untuk memulihkan kondisi stres yang dialaminya. Sayangnya, fakta-fakta ini seringkali diabaikan oleh perencana perkotaan maupun pembuat kebijakan kesehatan masyarakat.

Penelitian lain yang dilakukan oleh Welsch (Gonzalez-Gomez, 2014) terhadap 54 negara mengidentifikasikan dampak negatif dari polusi udara perkotaan terhadap subjective well-being warganya. Israel \& Levinson (dalam Gonzalez-Gomez, 2014) melakukan penelitian cross sectional terhadap 30 negara untuk mengukur dampak peningkatan pencemaran air terhadap kebahagiaan dan kepuasan hidup. Hasilnya, semakin tinggi tingkat pencemaran air yang terjadi di suatu negara, semakin rendah kepuasan hidup warganya. Fenomena serupa juga ditemukan oleh Evans \& Clark et al, (dalam Gonzalez-Gomez, 2014). Menurutnya, seorang individu yang tinggal di dalam sel penjara akan memiliki kesejahteraan psikologis yang lebih buruk dibandingkan dengan orang yang dapat berinteraksi bebas dengan lingkungannya. Hal ini dikarenakan individu yang berada di dalam sel penjara tidak dapat berinteraksi secara langsung atau tidak dapat berkontribusi secara langsung terhadap lingkungannya sehingga individu tersebut memiliki tingkat kepuasan hidup yang rendah.

Untuk mempertahankan kondisi well-beingnya, individu perlu terlibat dalam aktivitas yang dapat merestorasi fungsi kognitifnya, terutama atensi (Hartig, Kaiser, Strumse, 2007). Aktivitas tersebut mencakup segala aktivitas yang dapat meredakan ketegangan fisiologis dan emosi setelah melalui hari yang penuh tekanan, ataupun memulihkan kapasitas untuk memusatkan perhatian setelah seharian menyelesaikan tugas yang sulit (Ulrich et al. 1991; Kaplan 1995; Hartig 2004). Sejumlah riset menyebutkan bahwa pengalaman positif individu di lingkungan yang natural merupakan salah satu sumber terbaik untuk memulai proses restorasi. Dibandingkan bentuk lingkungan lainnya, lingkungan yang kaya dengan fitur-fitur alami merupakan lingkungan paling restoratif. Survei yang dilakukan sejak tahun 1960, secara konsisten menunjukkan bahwa penurunan tingkat stres dan melarikan diri dari tekanan hidup adalah alasan utama seseorang memutuskan berekreasi ke luar (Hartig et al., 2007). Alasan ini bukan hanya berkaitan dengan aktivitas rekreasionalnya tetapi juga kombinasi antara aktivitas yang dilakukan dengan fitur-fitur yang dihadirkan oleh alam.

Sejumlah penelitian eksperimental telah menunjukkan bahwa semakin besar kebutuhan seseorang untuk merestorasi kondisi psikologisnya, maka semakin besar preferensinya untuk berjalan di area natural dibandingkan di pusat perkotaan (Staatset al 2003; Staats
\& Hartig 2004; Hartig \& Staats 2006). Percobaan lapangan telah menemukan bahwa restorasi atensi dan pemulihan stres psikofisiologis dapat dilakukan dengan lebih baik melalui aktivitas berjalan-jalan menyusuri lingkungan alam pedesaan dibandingkan jika dilakukan di lingkungan perkotaan (Hartiget al. 1991, 2003).

Penelitian ini dilakukan untuk menemukan setting lingkungan yang berpotensi meningkatkan kesejahteraan psikologis individu setelah mengalami kondisi yang penuh tekanan melalui pengukuran efek restoratif yang dirasakan oleh responden. Dengan pendekatan eksperimental, penelitian ini bertujuan melihat perbandingan efek restoratif yang dioperasionalisasikan dalam bentuk pengukuran tingkat stres pada responden berdasarkan perbedaan paparan visual jenis lingkungan: lingkungan natural (natural environment) dan lingkungan terbangun (built environment). Sejauh ini belum ada kajian yang membahas perbedaan efek restoratif berdasarkan jenis lingkungan terhadap penurunan tingkat stres pada populasi masyarakat perkotaan di Indonesia, sementara jumlah dan tingkatmasalah kesehatan khususnya kesehatan psikologis masyarakat urban terus meningkat. Penelitian dengan pendekatan eksperimen terkait isu psikologi lingkungan dan kesehatan mental juga belum pernah dilakukan sebelumnya di Indonesia. Dengan demikian, penelitian ini bertujuan untuk melihat pengaruh perbedaan efek restoratif terhadap kaum urban berdasarkan jenis lingkungan dengan pendekatan laboratory experiment. Secara khusus, pertanyaan penelitian ini adalah "apakah terdapat perbedaan efek restoratif berdasarkan paparan visual jenis lingkungan dalam meningkatkan kesejahteraan psikologis individu?".

\section{Natural Environment dan Built Environment}

Alam merupakan atribut dari setiap kota yang berkaitan dengan pemandangan luas baik di dalam perbatasan maupun di luar perbatasan meskipun kota adalah ruang infrastruktur dan sosial. Ruang hijau dapat menumbuhkan kesejahteraan fisik dan psikologis bagi manusia, ruang hijau di perkotaan tidak hanya mencakup taman kota, tetapi juga terdiri dari pepohonan di jalan dan ruang terbuka untuk masyarakat. Dalam sebuah penelitian yang dilakukan oleh Taylor, Kuo \& Sullivan (dalam Collado \& Corraliza, 2010) individu yang tinggal di rumah dengan pemandangan hijau menunjukkan disiplin yang lebih tinggi. Wells \& Lekies (dalam Collado \& Corraliza, 2010) partisipasi seseorang dalam kegiatan seperti hiking, bermain di hutan atau merawat tanaman selama masa kanak-kanak memiliki pengaruh positif pada sikap mereka terhadap lingkungan ketika dewasa.

Segala sesuatu yang dibuat, disusun dan dipelihara oleh manusia untuk memenuhi keperluan manusia untuk menengahi lingkungan secara keseluruhan dengan hasil yang memengaruhi konteks lingkungan (built environment). Corraliza (2012) menyatakan bahwa ketika seseorang berada di lingkungan natural, 
mereka secara signifikan menerima efek rstoratif lebih tinggi dibandingkan individu yang tingga di wilayah nonnatural. Tennessen \& Cimprich (dalam Collado \& Corraliza, 2015) melakukan studi yang menunjukkan bahwa siswa yang memiliki jendela di kamar asrama dengan pemandangan lingkungan alam memiliki perhatian lebih baik daripada siswa yang jendela kamar asramanya memberikan pemandangan built.

Wells \& Evans (dalam Collado \& Corraliza, 2015) menyatakan bahwa individu yang setiap hari berkontak dengan lingkungan alam baik di rumah dan di sekolah menunjukkan tingkat stres yang lebih rendah. Pada populasi anak, Matsuoka (dalam Collado \& Corraliza, 2015) siswa yang terpapar lingkungan alam selama berada di sekolah berhubungan positif dengan kinerja mereka.

\section{Attention Restoration Theory (ART)}

Penelitian ini menggunakan kerangka teori ART sebagai pedoman eksperimen. ART dikembangkan pertama kali oleh Kaplan (1995). Menurut Kaplan, kelelahan mental dan konsentrasi dapat ditingkatkan dengan menghabiskan waktu, atau melihat alam. Kapasitas otak untuk fokus pada rangsangan atau tugas tertentu terbatas dan menghasilkan 'kelelahan atensi'. ART mengusulkan agar paparan lingkungan alami dapat dioptimalkan guna mendorong fungsi otak yang lebih mudah, sehingga memungkinkannya pulih dan mengisi kapasitas perhatian yang diarahkannya.

Menurut Kaplan, lingkungan yang dipersepsi sebagai lingkungan yang restoratif harus memenuhi kriteria berikut:

- Luas (ruang lingkup untuk merasakan tenggelam dalam lingkungan).

- Memberikan kesan "berada jauh dari rutinitas" bagi individu.

- Memukau (aspek lingkungan yang menarik perhatian dengan mudah).

- Kompatibilitas (individu pasti ingin terpapar, dan menghargai lingkungan tertentu).

\section{METODE}

\section{Jenis Penelitian}

Penelitian ini merupakan penelitian kuantitatif dengan pendekatan eksperimental, yaitu dengan mengukur pengaruh variabel bebas (paparan visual jenis lingkungan) terhadap variabel tergantung (efek restoratif, yang diukur melalui penurunan level stres).

\section{Rancangan Penelitian}

Penelitian ini menggunakan rancangan penelitian laboratory experimental karena keseluruhan aktivitas pengambilan data dilakukan dalam situasi yang terkontrol ketat, dengan pemberian manipulasi pada dua kelompok eksperimen serta dilakukan randomisasi pada sampel penelitian.
Secara garis besar, penelitian ini merupakan jenis penelitian eksperimen dengan desain anavar satu jalan. Artinya, akan ada dua kelompok penelitian eksperimen yang dilibatkan dalam penelitian ini. Kelompok eksperimen pertama akan mendapatkan paparan visual berupa lingkungan natural. Kelompok eksperimen kedua akan mendapatkan paparan visual berupa lingkungan terbangun. Kerangka prosedur penelitian yang digunakan dalam penelitian ini dapat dilihat pada Gambar 1 .

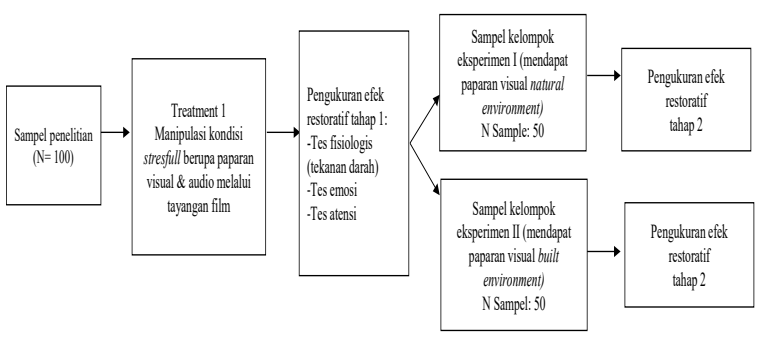

Gambar 1. Prosedur Penelitian

Penelitian ini menggunakan pendekatan laboratory experiment yang memiliki sejumlah kelebihan dan kekurangan. Kelebihan dari penelitian ini adalah adanya kontrol yang cukup ketat baik dalam hal alat ukur, instruksi maupun kondisi subjek, sehingga peneliti dapat meyakini bahwa hanya variabel bebaslah (stimulus audio visual) yang mempengaruhi variabel terikat (efek restoratif yang diukur melalui tingkat stres). Meski demikian penelitian eksperimen seringkali lemah dalam validitas eksternal, karena penelitian ini tidak bertujuan untuk generalisasi hasil pada populasi. Artinya, hasil dalam penelitian ini sulit diterapkan pada kondisi nyata dalam keseharian subjek dan cenderung tidak bisa dibandingkan dengan penelitian lain terutama yang menerapkan pendekatan noneksperimental.

\section{Partisipan}

Sampel penelitian ini adalah masyarakat Jakarta yang telah menetap/tinggal di Jakarta dalam 3 tahun terakhir. Adapun karakteristik sampel penelitian ini yaitu masyarakat umum dengan jenis kelamin lakilaki dan perempuan yang berusia 18-30 tahun. Jumlah sampel yang ditargetkan dalam penelitian ini adalah sebanyak 100 responden yang kemudian dibagi rata dalam setiap kelompok eksperimen. Penelitian eksperimen dengan desain between subject merupakan penelitian $\mathrm{N}$ besar, artinya setiap kelompok eksperimen setidaknya melibatkan 40 responden.

\section{Instrumen Penelitian}

Sejauh ini, pengukuran efek restoratif suatu lingkungan lebih banyak menggunakan kuesioner persepsi yang diisi langsung oleh para pengguna atau pengunjung dari suatu lingkungan. Meski demikian, pengukuran objektif yang berkaitan langsung dengan restoraction effect masih belum banyak 
diujicobakan, dan di Indonesia sendiri belum pernah dilakukan sebelumnya. Untuk mengetahui apakah fungsi atensi seseorang telah kembali setelah mengalami atau merasakan efek restoratif dalam bentuk penurunan tingkat stres dari suatu lingkungan, pengukuran objektif dapat dilakukan melalui tiga cara, yakni:

- Pengukuran fisiologis berupa pengukuran tensi darah. Dalam sejumlah penelitian disebutkan bahwa, seseorang dengan level stres yang rendah cenderung memiliki tekanan darah yang normal dan atau lebih rendah dari mereka yang mengalami tingkat stres tinggi. Sebaliknya, individu yang mengalami stres cenderung memiliki tekanan darah yang lebih tinggi. Dengan demikian, jika responden dalam penelitian ini mengalami perubahan menuju tekanan darah normal pasca menerima stimulus, dapat dikatakan ia telah menerima efek restoratif dari paparan visual tersebut.

- Pengukuran atensi. Atensi secara umum terbagi atas dua, yakni involuntary attention dan directed attention. Di antara keduanya, directed attention adalah yang paling mudah mengalami kelelahan karena membutuhkan usaha yang lebih keras untuk memainkan fungsinya dalam keseharian, seperti mengambil keputusan, membuat rencana, menyelesaikan masalah, dan membuat prioritas. Dalam penelitian ini, pengukuran objektif yang paling mungkin diukur adalah directed attention karena paling mudah untuk diukur perubahan tingkat kelelahannya dan orang dengan tingkat stres yang rendah cenderung memiliki directed stres yang lebih baik. Pengukuran directed attention dalam penelitian ini menggunakan sebuah simulasi permainan kombinasi warna dan huruf yang harus dicocokkan oleh responden. Semakin tinggi skor yang dihasilkan responden dalam permainan ini, menunjukkan pengaruh stimulas terhadap directed attention yang lebih baik dan berfungsi optimal (tidak mengalami kelelahan).

- Pengukuran emosi. Individu yang merasakan efek restoratif dari suatu stimulus lingkungan diprediksi memiliki emosi yang lebih baik dan kondisi mood yang secara umum lebih positif. Hal ini dikarenakan individu dapat menjalankan fungsi atensinya sesuai dengan kebutuhan dari suatu aktivitas/tugas (tidak terjadi kelebihan beban atensi). Pengukuran emosi dalam penelitian ini dilakukan dengan memberikan kuesioner skala emosi, dimana responden diminta untuk melaporkan kondisi emosinya sebelum dan sesudah mendapatkan paparan stimulasi visual yang telah disiapkan eksperimenter. Semakin tinggi nilai yang diberikan oleh responden, menunjukkan kondisi emosi yang semakin positif. Jika skor responden pasca menerima stimulasi visual lebih tinggi dibandingkan sebelum menerima manipulasi, maka dapat disimpulkan bahwa responden merasakan efek restoratif dari paparan visual yang diterimanya.

Berdasarkan hal tersebut, pada penelitian ini digunakan tiga instrumen untuk mengukur pengalaman/ efekrestoratif yang dirasakan oleh responden pasca terpapar stimulus visual desain lingkungan tertentu, yaitu:

\section{-Pengukuran Fisiologis}

Instrumen: alat pengukur tensi darah (jenis elektronik)

\section{-Pengukuran Emosi}

Instrumen: skala emosi (self-report)

\section{-Pengukuran Directed Attention}

Instrumen: permainan attention (menggunakan visual game).

\section{Analisis Data}

Data hasil penelitian ini dianalisis dengan menggunakan uncorrelated t-test dari gained score masing-masing kelompok eksperimen. Teknik statistik ini digunakan karena penelitian ini melibatkan dua variasi variabel bebas dan satu variabel tergantung pada dua kelompok yang berbeda.

\section{HASIL DAN PEMBAHASAN}

\section{Deskripsi Subjek Penelitian}

Tabel 1. Demografi Subjek

\begin{tabular}{lrr}
\hline \multicolumn{1}{c}{ Variabel } & Jumlah & Persentase \\
\hline USIA & 92 & \\
18 -25 tahun & & $100 \%$ \\
JENIS KELAMIN & 37 & $40 \%$ \\
Laki-laki & 55 & $60 \%$ \\
Perempuan & & \\
PENDIDIKAN TERAKHIR & 92 & $100 \%$ \\
SMA/SMK & 92 \\
\hline
\end{tabular}

\section{Deskripsi Kategori Penelitian}

Berdasarkan Tabel 2 dapat disimpulkan bahwa terjadi sejumlah perubahan pada aspek fisiologis, emosi, dan atensi responden sebelum dan sesudah terpapar stimulus audio-visual lingkungan yang natural. Pada aspek fisiologis yang diukur melalui tekanan darah, terjadi penambahan jumlah responden dengan tekanan darah normal (90/60-120/80). Selanjutnya, pada aspek atensi, mean skor responden dalam kelompok nature meningkat sebanyak 260 poin. Sementara itu, pada aspek emosi, responden menunjukkan perubahan emosi yang jauh lebih positif setelah terpapar stimulus natural. Pada pre-test, sebanyak 32 responden menyatakan emosinya negative, dan sesudah terpapar stimulus, jumlah tersebut berkurang hanya menjadi empat orang.

Tabel 2. Kategori Skor pada Kelompok Nature $(\mathrm{N}=48)$ 


\begin{tabular}{|c|c|c|c|c|c|c|c|}
\hline \multicolumn{4}{|c|}{ Pre-test } & \multicolumn{4}{|c|}{ Post-test } \\
\hline Variabel & Kategori & Frekuensi & $\%$ & Variabel & Kategori & Frekuensi & $\%$ \\
\hline \multirow{3}{*}{ Tekanan Darah } & Tinggi & 10 & 20 & \multirow{3}{*}{ Tekanan Darah } & Tinggi & 5 & 10 \\
\hline & Normal & 26 & 50 & & Normal & 35 & 70 \\
\hline & Rendah & 12 & 30 & & Rendah & 8 & 20 \\
\hline \multirow{2}{*}{ Atensi (mean: 263) } & Tinggi $(>263)$ & 18 & 40 & \multirow{2}{*}{ Atensi (mean: 523) } & Tinggi (>523) & 16 & 30 \\
\hline & rendah $(<263)$ & 30 & 60 & & rendah $(<523)$ & 32 & 70 \\
\hline \multirow{2}{*}{ Emosi } & Positif (5-7) & 16 & 30 & \multirow{2}{*}{ Emosi } & Positif (5-7) & 44 & 90 \\
\hline & Negatif (1-4) & 32 & 70 & & Negatif (1-4) & 4 & 10 \\
\hline
\end{tabular}

Tabel 3. Kategori Skor pada Kelompok Built $(\mathrm{N}=44)$

\begin{tabular}{|c|c|c|c|c|c|c|c|}
\hline \multicolumn{4}{|c|}{ Pre-test } & \multicolumn{4}{|c|}{ Post-test } \\
\hline Variabel & Kategori & Frekuensi & $\%$ & Variabel & Kategori & Frekuensi & $\%$ \\
\hline \multirow{3}{*}{ Tekanan Darah } & Tinggi & 8 & 20 & \multirow{3}{*}{ Tekanan Darah } & Tinggi & 12 & 30 \\
\hline & Normal & 32 & 70 & & Normal & 32 & 70 \\
\hline & Rendah & 4 & 10 & & Rendah & 0 & 0 \\
\hline \multirow{2}{*}{ Atensi (mean: 241) } & Tinggi $(>241)$ & 16 & 40 & \multirow{2}{*}{ Atensi (mean: 691) } & Tinggi $(>691)$ & 19 & 40 \\
\hline & rendah $(<241)$ & 28 & 60 & & rendah $(<691)$ & 25 & 60 \\
\hline \multirow{2}{*}{ Emosi } & Positif (5-7) & 10 & 20 & \multirow{2}{*}{ Emosi } & Positif (5-7) & 37 & 80 \\
\hline & Negatif (1-4) & 34 & 80 & & Negatif (1-4) & 7 & 20 \\
\hline
\end{tabular}

Dari Tabel 3, dapat disimpulkan bahwa perubahan signifikan pada kelompok built terjadi pada aspek atensi dan emosi. Perubahan mean kelompok built meningkat sebesar 450 poin, dari yang sebelumnya (pada pre-test) sebesar 241 menjadi 691 (pada post-test). Peningkatan skor rerata atensi pada kelompok tersebut juga diiringi oleh peningkatan jumlah responden pada kategori tinggi. Pada aspek emosi, sebagian besar responden juga merasakan adanya perubahan emosi yang menjadi lebih positif setelah terpapar stimulus built. Pada pretest skala emosi, sebanyak 34 responden menyatakan bahwa dirinya merasakan emosi yang negatif namun pada saat post-test, jumlah tersebut jauh berkurang dan hanya menyisakan tujuh orang responden saja dengan emosi negatif.

\section{Uji Hipotesis}

Tabel 4. Tabel Rata-Rata Gained Score Kelompok Nature dan Kelompok Built

\begin{tabular}{llrrrr}
\hline & Grup & Sistol & Diastol & Atensi & Emosi \\
\hline \multirow{2}{*}{ Nature } & Mean & $-3,65$ & $-3,37$ & $\mathbf{2 6 0 , 2 1}$ & $\mathbf{1 , 6 9}$ \\
& N & 48 & 48 & 48 & 48 \\
& Std. Deviation & 10,674 & 22,490 & 403,535 & 1,560 \\
Built & Mean & $-3,36$ &, 18 & $\mathbf{4 4 9 , 7 7}$ & $\mathbf{7 5}$ \\
& N & 44 & 44 & 44 & 44 \\
& Std. Deviation & 21,477 & 11,469 & 458,590 & 1,512 \\
Total & Mean & $-3,51$ & $-1,86$ & 350,87 & 1,24 \\
& N & 92 & 92 & 92 & 92 \\
& Std. Deviation & 16,638 & 18,090 & 438,799 & 1,599 \\
\hline
\end{tabular}

Tabel 5. Uji T-Test Variabel-Variabel Tergantung Pada Kedua Kelompok Eksperimen

\begin{tabular}{ccc}
\hline Variabel yang Diukur & T & \multicolumn{1}{l}{ Sig. } \\
\hline Tekanan darah (sistol) & $-0,81$ & 0,936 \\
Tekanan darah (diastol) & $-1,036$ & 0,303 \\
Atensi & 2,109 & $\mathbf{0 , 0 3 8 ^ { \star }}$ \\
Emosi & 2,923 & $\mathbf{0 , 0 0 4}^{\star}$ \\
\hline
\end{tabular}

Berdasarkan hasil perhitungan $t$-test pada Tabel 5, dapat disimpulkan bahwa hanya aspek atensi dan emosi yang menunjukkan perbedaan skor yang signifikan pada kedua kelompok eksperimen karena memiliki nilai signifikansi di bawah 0.005 (t atensi $=2.109$, sig= 0.038 ; $\mathrm{t}$ emosi $=2.923$, sig=0.004). Sementara itu, dari Tabel 4, dapat dilihat bahwa atensi kelompok built lebih baik dibandingkan kelompok nature. Akan tetapi, kelompok nature memiliki perubahan emosi yang lebih positif dibandingkan kelompok built.

Secara operasional, pengukuran efek restoratif dalam penelitian ini dilakukan dengan cara mengukur tingkat stres responden dalam dua kelompok eksperimen yang mendapatkan dua perlakuan yang berbeda. Berdasarkan hasil penelitian, diketahui bahwa terdapat perbedaan atensi dan emosi yang signifikan berdasarkan jenis stimulus yang diterima responden $(\mathrm{t}$ atensi $=2.109$, sig $=0.038$; $\mathrm{t}$ emosi $=2.923$, sig $=0.004$ ). Artinya, jenis stimulus lingkungan yang berbeda dapat menghasilkan respon stres yang berbeda pada individu. Dengan kata lain, stimulus lingkungan yang berbeda 
juga berpotensi memberikan efek restoratif yang berbeda pada individu.

Penelitian ini mendukung sekaligus memunculkan hasil yang berbeda dari penelitian-penelitian serupa sebelumnya. Dalam penelitian ini, responden yang terpapar stimulus audio-visual berupa jenis lingkungan yang sarat fitur alam memiliki perubahan emosi yang lebih positif dibandingkan responden yang terpapar stimulus lingkungan built (video dengan fitur yang dengan situasi perkotaan: bangunan yang padat, situasi jalan raya yang ramai, dan penduduk yang berlalu lalang). Temuan ini sejalan dengan penelitian yang dilakukan oleh Beil \& Hanes (2013) yang menyimpulkan dalam penelitian eksperimen lapangan yang mereka lakukan bahwa semakin tinggi frekuensi seseorang berinteraksi dengan lingkungan yang memiliki fitur-fitur natural, maka semakin rendah tingkat stresnya yang diukur melalui salivary analyses dan self-reported stress. Perbedaan ini semakin terlihat nyata pada subjek perempuan dalam penelitian Beil \& Hanes (2013). Meski demikian, penelitian ini tidak membedakan gender subjek dalam pengukuran karena adanya proses randomisasi, dimana faktor-faktor bawaan subjek dianggap konstan pada kedua kelompok eksperimen.

Temuan dalam penelitian ini yang berkaitan dengan aspek emosi juga mendukung beragam hasil riset terdahulu. Penelitian di beberapa negara juga melaporkan bahwa lingkungan alamiah memberikan efek yang lebih baik pada kondisi emosional, fisiologis, efek restoratif (Hartig, Evans, Jamner, Davis, \& Gärling, 2003; Hartig \& Staats, 2003; Laumann, Gärling, \& Stormark, 2003; Morita, Fukuda, Nagano, Hamajima, Yamamoto, Iwai, Nakashima, Ohira, \& Shirakawa, 2007 dalam Takayama, Korpela, Lee, Morikawa, Tsunetsugu, Park, Li, Tyrväinen, Miyazaki, \& Kagawa, 2014)

Perbedaan lain yang signifikan dan ditemukan dalam penelitian ini berkaitan dengan aspek atensi responden. Responden pada kelompok yang mendapatkan stimulus berupa situasi lingkungan built justru cenderung mengalami peningkatan kapasitas atensi dibandingkan responden yang mendapatkan stimulus natural. Temuan ini menjadi menarik sebab dalam banyak riset terdahulu, disebutkan bahwa lingkungan alamiah cenderung akan mendukung peningkatan kapasitas atensi responden dibandingkan lingkungan built. Sebagai perbandingan, riset yang dilakukan oleh Ohly, White, Wheele, Bethel, Ukoumunne, Nikolaou, \& Garside (2016) menunjukkan bahwa responden yang dipaparkan stimulus alamiah menunjukkan skor atensi yang lebih baik dibandingkan responden yang dipaparkan stimulus setting nonalamiah. Perbedaan hasil antara riset Ohly et al. (2016) dan penelitian ini sangat mungkin terjadi karena adanya perbedaan alat ukur. Ohly et al. (2016) melakukan pengukuran atensi dengan menggunakan DSF (Digit Span Forward), DSB (Digit Span Backward), dan TMTB (Trail Making
Test $B$ ) yang sarat dengan stimulus auditori, sementara penelitian ini menggunakan pengukuran directed attention berupa tugas color-word matching yang diberikan secara visual.

Pada penelitian yang dilakukan oleh Tyrvainen et al. (2014) yang melakukan penelitian field experiment mengenai pengaruh interaksi langsung dengan beragam jenis lingkungan terhadap penurunan stres menunjukkan bahwa terjadi penurunan tekanan darah yang signifikan pada responden dengan tekanan darah relative tinggi saat mereka berada di lingkungan natural dan melihat pemandangan. Akan tetapi, hasil dari penelitian ini tidak menemukan hasil yang mendukung temuan Tyrvainen et al. (2014). Berdasarkan hasil pengukuran tekanan darah sebelum maupun sesudah responden mendapatkan stimulus, tidak ada perbedaan perubahan tekanan darah yang signifikan pada kedua kelompok. Penelitian ini menunjukkan bahwa terdapat perbedaan efek restoratif yang diarasakan oleh responden yang dipaparkan stimulus audio-visual jenis lingkungan nature dan jenis lingkungan built berdasarkan pengukuran tingkat stres.

\section{SIMPULAN}

Hasil penelitian ini menunjukkan adanya perbedaan efek restoratif yang dirasakan oleh responden yang dipaparkan stimulus audio-visual jenis lingkungan nature dan jenis lingkungan built berdasarkan pengukuran tingkat stres. Secara khusus, perbedaan tersebut terlihat signifikan pada aspek emosi dan atensi, namun tidak menunjukkan perbedaan signifikan pada aspek fisiologis yang diukur melalui tekanan darah. Pada aspek emosi, subjek yang mendapatkan stimulus nature menunjukkan respon emosi yang lebih positif dibandingkan subjek dengan stimulus built. Sebaliknya, pada aspek atensi, subjek yang menerima stimulus built menunjukkan peningkatan kapasitas atensi yang lebih baik dibandingkan subjek pada kelompok nature.

Untuk penelitian selanjutnya, peneliti menyarankan adanya variasi stimulus yang lebih kompleks dengan menggunakan alat-alat eksperimen yang lebih memadai. Misalnya, penelitian ini hanya memanfaatkan layar monitor sebesar 40 inch, sehingga subjek diposisikan sebagai "penonton" pada tayangan yang diberikan. Padahal untuk memberikan efek berinteraksi pada suatu ruang, seseorang membutuhkan tampilan yang setidaknya sama dengan ukuran tubuhnya sebagaimana yang disimpulkan oleh Hou, Nam, Peng, Lee (2014). Dalam risetnya, Hou et al. (2012) menyatakan bahwa ukuran layar menentukan sensasi fisik dan self-presence yang dirasakan seseorang saat ia melihat apa yang ditampilkan dalam layar, dan kedua efek tersebut baru akan terasa signifikan jika subjek menggunakan layar dengan ukuran minimal 81 inch. 
Selain penggunaan alat yang lebih memadai, peneliti juga menyarankan adanya bentuk operasional lain dari pengukuran efek restoratif. Dalam penelitian ini, pengukuran tingkat stres dipilih karena responnya paling mudah diamati dan bersifat objektif (bukan sekadar persepsi subjek). Meski demikian dalam mengukur aspek emosi, peneliti hanya menggunakan self-reported emotion scale dimana subjek hanya diminta menilai secara subjektif kondisi emosinya pada saat pelaksanaan eksperimen. Akan tetapi, dalam literature lain disebutkan bahwa efek restoratif yang melibatkan aspek emosi juga dapat diukur melalui vocal expressions of anger, joy dan emotional naturality (Korpela \& Hietanen, 2002), dimana ketiga pengukuran tersebut bersifat lebih objektif dan memiliki presisi yang tinggi.

\section{DAFTAR PUSTAKA}

Adli, M., (2011), 'Urban stres and mental health', LSE Cities, available at: http://secities.net/ media/ objects/articles/urban-stres-and-mental-health/en$\mathrm{gb} /$ (accessed 8 January 2015).

Beil,K.\&Hanes, D. (2013). The Influence ofUrban Natural and Built Environments on Physiological and Psychological Measures of Stres - A Pilot Study. International Journal of Environmental Research and Public Health. 10, 1250-1267.

Baron, R. A., \& Ransberger, V. M. (1978). Ambient temperature and the occurrence of collective violence: The "Long, hot summer" revisited. Journal of Personality and Social Psychology, 36, 351-360.

Burls, A. (2007) "People and green spaces: promoting public health and mental well-being through ecotherapy", Journal of Public Mental Health, 6(3), 24-39.

Collado, S., \& Corraliza, J. A. (2015). Environment and Behavior. Children's Restoratif Experiences and Self-Reported Environmental Behaviors, 43.

Dhewanthi, L. (2015). Indeks Kualitas Lingkungan Hidup Indonesia tahun 2014. Jakarta: Kementrian lingkungan Hidup dan Kehutanan.

Gonzalez-Gomez, M. S.-V. (2014). Applied Research Quality Life. Do Pro-Environemntal Behaviors And Awareness Contribute To Improve Subjective Well Being? Journal Psychology.

Hartig T, Evans G.W, Jamner L.D, Davis D.S, \& Gärling T. (2003). Tracking restoration in natural and urban field settings. Journal of Environmental Psychology, 23, 109-123.

Hartig, T., \& Staats, H. (2006). The need for psychological restoration as a determinant of environmental preferences. Journal of Environmental Psychology, 26, 215-226.

Hartig T., Kaiser F.G. \& Strumse E. (2007). Psychological restoration in nature as a source of motivation for ecological behavior. Environmental ConservatioN, 34, 291-299.

Hartig, T., Kaiser, F. G., \& Bowler, P. (2004). Psychological restoration in nature as a positive motivation for ecological behavior. Environment and Behavior, 590-607.

Hou, J., Nam, Y., Peng, W., Lee, K. (2012). Effects of screen size, viewing angle, and players' immersion tendencies on game experience. Computers in Human Behavior, 617-623.

Kaplan, S. (1995). The restoratif benefits of nature: Towards an integrative framework. Journal of Environmental Psychology, 169-182.

Korpela, K. \& Hietanen, J. (2002). Evidence for Rapid Affective Evaluation of Environmental Scenes. Environmental and Behavior, 34(5), 634-650.

Ohly, H., White, M. P., Wheeler, B. W., Bethel, A., Ukoumunne, O. C., Nikolalou, V. \& Garside, R. (2016). Attention Restoration Theory: A Systematic Review of the A t $t$ e $n t$ i o $n$ RestorationPotential of Exposure to Natural Environments. Journal of Toxicology and Environmental Health, 19(7), 305-343.

Staats, H., \& Hartig, T. (2004). Alone or with a friend: A social context for psychological restoration and environmental preferences. Journal of Environmental Psychology, 24, 199-211.

Staats, H., Kieviet, A., \& Hartig, T. (2003). Where to recover from attentional fatigue: An expectancy value analysis of environmental preference. Journal of Environmental Psychology, 23, 147157.

Takayama, N. dkk. (2014). Emotional, Restoratif and Vitalizing Effects of Forest and Urban Environments at Four Sites in Japan. International Journal of Environmental Research and Public Health. 11, 7207-7230.

Ulrich, R. S., Simons, R. F., Losito, B. D., Fiorito, E., Miles, M. A., Zelson, M. (1991). Stres Recoverry during Exposure to Natural and Urban Environments. Journal of Environmental Psychology 11, 201-230

Wiwanitkit, V. (2010). Environmental Change And Psychological Impact. In J. Valentin, L. Gamez, editors. Environmental Psychology: New developments, 251-254. 